\title{
Longwall shearers for exploiting thin coal seams as well as thin and highly inclined coal seams
}

\begin{abstract}
Due to a number of advantages, mechanized longwall systems are applied to exploit seams characterized by a wide range of thicknesses. In the case of thin seams as well as thin and highly inclined ones, there are numerous solutions for longwall shearers that allow for the exploitation of coal seams with a minimum thickness of $0.4 \mathrm{~m}$ and a gradient of up to $85^{\circ}$. The article focuses on longwall systems designed for such seam mining. The most important assumptions and advantages of longwall exploitation are presented, and mining machines that are key elements of mechanized longwall systems are discussed. Attention has also been drawn to the various solutions of shearers that are currently used on the domestic market. A wide range of available solutions allowed for distinguishing and presenting ten types of shearers.
\end{abstract}

Key words: thin seams, inclined seams, mechanized mining, longwall systems, longwall shearers

\section{INTRODUCTION}

Extracting minerals from deposits starts from the most attractive ones in terms of profitability and technical difficulties. This is particularly important for underground mining. In the case of hard coal occurring in the form of beds, thin and highly inclined seams are very often omitted (as long as their exploitation is not necessary). However, in many countries, an increasing interest in these seams can be observed. This interest results largely from their considerable amounts as well as the necessity to rationally use all available sources of energy. Especially in recent years, more and more attention has been paid to the possibility of the commercially viable exploitation of thin and highly inclined seams. In the case of Poland, thin seams can be considered those that have a minimum thickness of $1.0 \mathrm{~m}$; however, in some countries, seams as thin as $0.4 \mathrm{~m}$ are selected (the upper limit is assumed to be $1.6 \mathrm{~m}$ ). Over $1.6 \mathrm{~m}$, the use of classic shearing (or plowing technology under favorable conditions) does not pose any problems typical of low excavations.

The most important element of a mechanized longwall mining system is the mining machine. The min- ing machine can be a longwall shearer or a static coal plow. Despite using only two types of machines, the range of available solutions is very wide. An analysis of the solutions currently available around the world (especially in the case of longwall shearers) allows us to conclude that particular types differ considerably from each other.

\section{SYSTEMS FOR LOW \\ AND HIGHLY INCLINED LONGWALLS}

Irrespective of its thickness, hard coal deposited in the form of a seam determines the manner of its exploitation. The most favorable way of mining a seam that allows for the highly efficient use of the deposit is longwall mining with a mechanized longwall system. This study is focused on presenting various solutions of the longwall shearer, which is the mining machine in the system. Shearers used in Poland as well as those that are not common on our market have been presented. This applies in particular to shearers applied for mining thin seams produced by the Chinese company Beijing HOT Mining Tech Co., Ltd. [1], shearers for seams that are both thin and highly inclined 
produced by the Spanish company Mackina-Westfalia, S.A. [2], and shearers produced by Corum Group [3]. All of the available products manufactured by companies whose offers include classic and the most frequently applied longwall shearers as well as static coal plows (including their technical parameters) have been discussed in book [4], whereas information on non-typical solutions applied under specific conditions can be found in articles $[5,6]$.

Mining with a longwall system involves cutting a coal seam with headings and connecting two headings with a longwall cross-cut having a length of $L$ corresponding to the longwall length and height $H$ - close to the thickness of the seam. The longwall can have a longitudinal slope of $\alpha$. These excavations form the mine face (Fig. 1). The longwall that has been made available by two headings ensures ventilation, the possibility for efficient transportation, and haulage of the output. Currently, a longwall working is equipped with a shearing or plowing mining system (which, similar to the longwall technology, have been described in literature [7-10]).

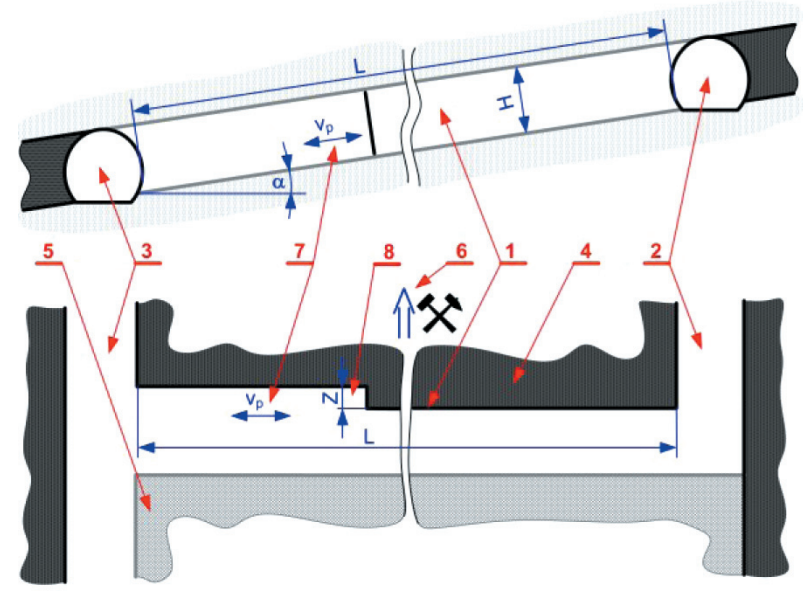

Fig. 1. Diagram of longwall working: 1 - face, 2 - top gate, 3 - bottom gate, 4 - unmined coal; 5 - goafs, 6 - exploitation direction, 7 - direction of machine cutting, 8 -web on solid coal, $v_{p}$-shearer's haulage speed, $a$-angle of longwall longitudinal inclination, $H$ - longwall's height,

$$
L \text { - longwall's length, } Z-\text { web }
$$

Equipped with a cutting machine, longwall conveyor, and powered support, the mechanized longwall mining system enables the process of solid coal cutting and loading as well as mined rock haulage from the longwall. Longwall systems differ depending on the height and length of the longwall, seam slope, and mining-geological conditions. The mining machine moves with a speed of $v_{p}$ and cuts the solid coal at a web depth of $Z$. Cutting can take place in one or two directions. Two-way mining is the most effective, whereas one-way mining is recommended in the case of problems with the cutting or loading of the mined rock.

Mechanized systems applied in highly inclined seams frequently differ from classic longwall shearing systems. It is worth having a closer look at these differences. In practice, these systems as well as the machines are adjusted each time to the local conditions and can differ significantly from one another due to changeable conditions. The system equipment in the case of longwalls with longitudinal inclinations ranging from $30^{\circ}$ to $85^{\circ}$ consists only of a shearer and powered support, whereas the armored face conveyor is located in the haulage heading below the chutes. A characteristic feature of the shearer applied is the lack of a fitted haulage drive and movement directly on the floor; that is, direct contact of the shearer's sliding plate with the floor. The shearer is hauled by a two-line winch, with one emergency line. Guiding along the exploited longwall is ensured by the shearer's slides (which are installed from the side of the goafs) and cooperate with the slide beams (which are connected with the support section feed mechanism). The shearer cuts the longwall when moving towards the top gate. Due to the high slope, the mined rock rolls down by itself towards the haulage heading. When the cutting is finished and the support has been pulled up, the shearer is lowered towards the niche (where the cutting process starts again) [7]. Apart from shearers cutting in highly inclined longwalls, plowing systems can also be applied [3, 4].

\section{CUTTING LONGWALL SHEARERS}

Irrespective of the thickness of a seam, the most popular longwall shearers are currently classic twocutting head shearers moving on a conveyor by means of a chainless haulage system. The longwall shearers used in Poland can be divided into three types:

- two-arm, two-head cutting shearers with a chainless haulage system and a frame over the conveyor (Fig. 2a);

- two-arm, two-head cutting shearers with a chainless haulage system with a frame running next to the conveyor (Fig. 2b);

- armless two-head cutting shearer with a chain haulage system (Fig. 2c) [5, 11]. 
However, when referring to the state-of-the-art of global technology, one should pay attention to the following types of shearers:

- two-arm, two-head cutting shearer with a chain haulage system;

- one-arm, one-head cutting shearer with a chainless haulage system;

- armless one-head cutting shearer (AGH concept) (Fig. 2d);

- armless two-head cutting shearer with vertical axles (Fig. 2c);

- two-arm, two-head cutting shearers with a chain haulage system for direct work on the floor (Fig. 2f);

- one-arm, one-head cutting shearer with a chain haulage system for direct work on the floor (Fig. 2g);

- armless one-head cutting shearer with a chain haulage system for direct work on the floor (Fig. 2h).

Historically, machines with different configurations of heads and drives have been applied in the global and Polish mining industry. In the aspect of thin seams, non-standard solutions intended for special conditions (for example, high inclinations or ultra-thin seams) are not applied in Poland. Apart from the best-known shearers, examples of mining machines offered by the above-mentioned companies (Mackina-Westfalia S.A., Beijing HOT Mining Tech Co., Ltd., and Corum Group) will be quoted as examples of interesting solutions, whereas detailed data as well as the remaining models can be found in the listed literature and in the producers' catalogs.

Established in 1961, Polish company Kopex Machinery S.A. [11] is known for the production of mining machines (longwall shearers in particular). Together with the KOPEX group, Kopex Machinery is currently a subsidiary of FAMUR S.A [12]. The KSW-460NE1 shearer (Fig. 3) is a narrow-arm longwall shearer with an electric haulage drive that moves on a conveyor. It has two arms and two heads. These features are typical of the classic shearers used for medium and thick seams. The Kopex KSW-460NE1 shearer is equipped with a control system with cutting memory that cooperates with the longwall system's superordinate control. It is designed to mine coal in longwalls with heights ranging from $1.35 \mathrm{~m}$ to $2.4 \mathrm{~m}$. The output of its cutting heads is $2 \times 200 \mathrm{~kW}$.

Established in 1864, German company Eickhoff Bergbautechnik GmbH [13] is known mainly for the production of longwall shearers. In its offer, Eickhoff has one shearer whose height of cutting partially overlaps the range of the thickness of thin seams. a)

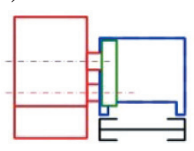

b)

c)

d)
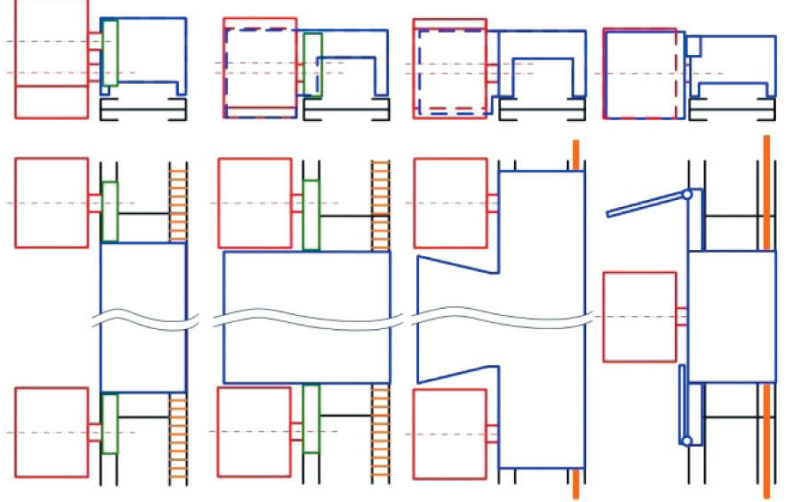

e)

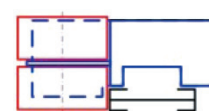

f)

g)

h)
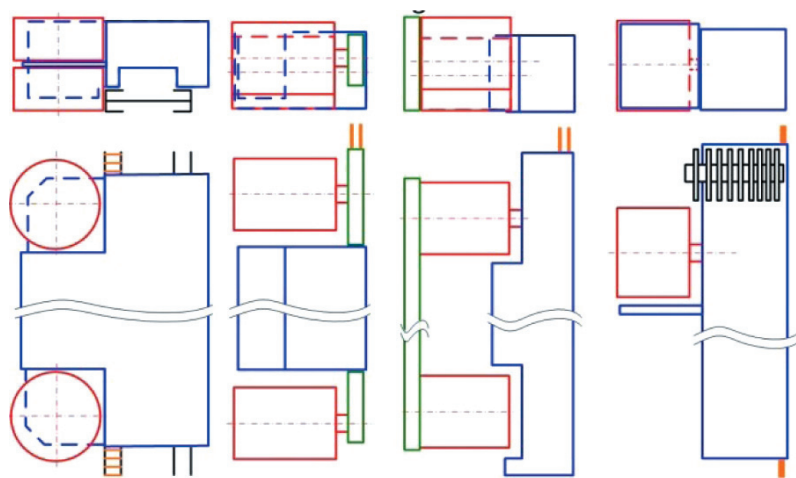

Fig. 2. Diagrams of selected types of longwall shearers for thin and inclined seams (blue - frame; red - cutting head; black - conveyor; green - mobile arm of cutting head; orange - haulage system): a) two-arm, two-head cutting shearer on conveyor, two-head cutting shearer on conveyor; b) two-arm, two-head cutting shearer next to conveyor; c) armless two-head cutting shearer; d) armless one-head cutting shearer designed by AGH; e) armless two-head cutting shearer with vertical axles; f) two-arm, two-head cutting shearer for direct work on floor; g) one-arm, two-head cutting shearer; h) armles one-head cutting shearer with conveyor

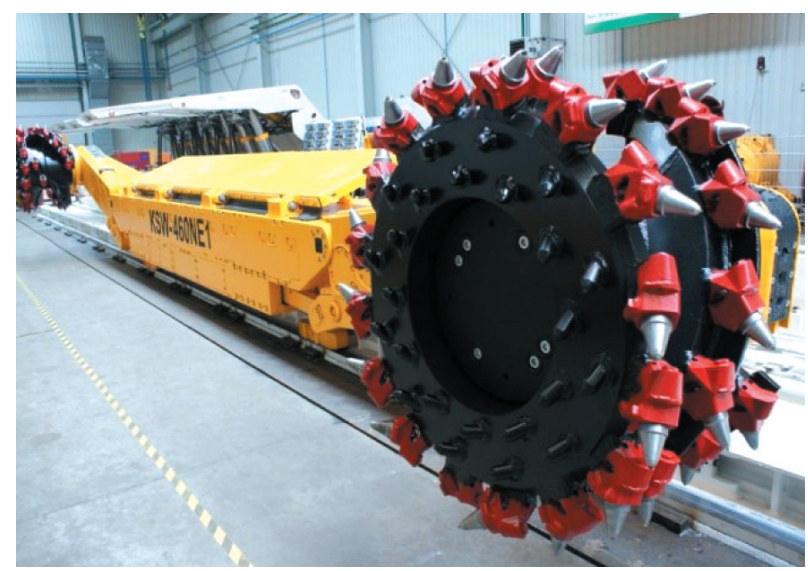

Fig. 3. KSW-460NE1 longwall shearer produced by Kopex Machinery 
This is the SL $300 \mathrm{~L}$ shearer, designed for work on longwalls whose heights range from $1.2 \mathrm{~m}$ to $2.0 \mathrm{~m}$ (Fig. 4).

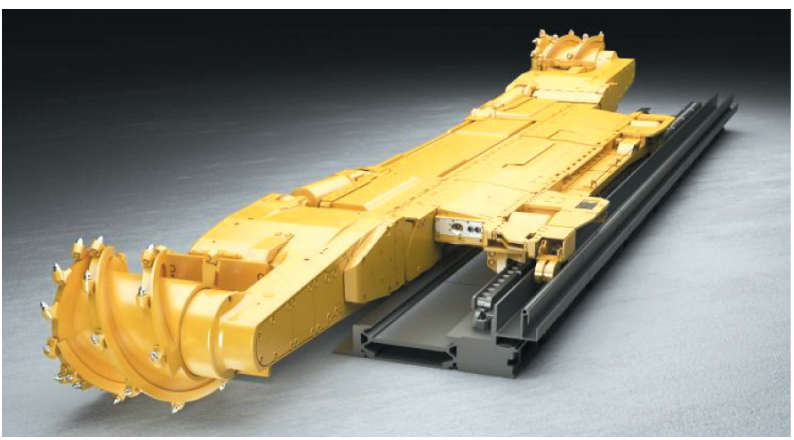

Fig. 4. SL 300 L longwall shearer produced by Eickhoff

The SL $300 \mathrm{~L}$ shearer is characterized by a twoarm, two-head construction. It is equipped with a chainless haulage system, and its frame moves along a conveyor. Unlike the competitors' products, the arms lifting the cylinders have been installed over the frame. The shearer is equipped with a $2 \times 300 \mathrm{~kW}$ drive of the cutting heads.

A unique solution developed by Kopex is the Mikrus system (Fig. 5) with a cutting-loading head (GUŁ-500) intended for two-way pocket-less cutting and loading of coal in thin seams. The range of the cutting height depends on the diameter of the cutting head applied (reaching 1.1-1.7 m). The GUŁ-500 shearer allows for changing the height of the cutting to a limited extent; the change can be made when the machine is stopped. The cutting-loading head is moved along the sidewall by means of a chain haulage system of the plowing type, which is driven by electric motors supplied from frequency converters placed in the headings. The shearer is characterized by twohead armless construction. Both heads are mechanically coupled and driven by one motor (with an output of $500 \mathrm{~kW}$ ).

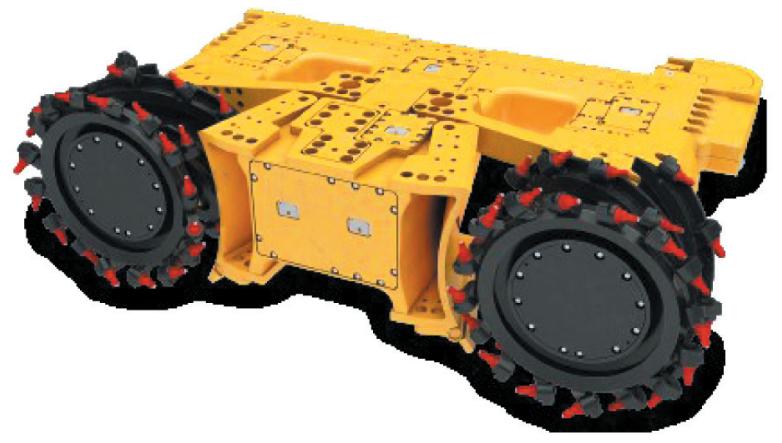

Fig. 5. Mikrus shearer GUE-500 produced by Kopex Machinery
Established in 1889, Ukrainian company Corum Group produces underground mining machines. Corum offers a unique longwall shearer solution the KBT200 (Fig. 6). The shearer is moved on a conveyor by means of a chainless haulage system. The characteristic feature is its armless construction and its cutting head axles that can turn $90^{\circ}$. Vertical axles enable the easier cutting and loading of the mined rock onto the conveyor. The KBT200 shearer is designed for mining coal from seams with thicknesses within a range of $0.8 \mathrm{~m}$ to $1.25 \mathrm{~m}$.

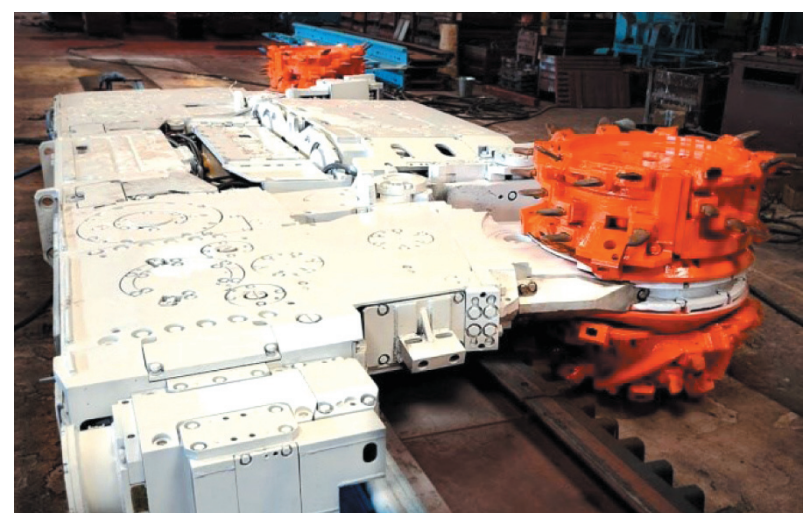

Fig. 6. KBT200 longwall shearer produced by Corum

Mackina-Westfalia S.A. started operating in 1955. It designs and produces mining machines among other things. In 1994, Mackina became independent from the German company Westfalia Lünen while maintaining the profile of its activity.

The two-arm, two-head cutting shearer with a PMAP Mackina chainless haulage system is characterized by classic construction and moves along a conveyor, but it will be presented in more detail due to its constructional features and solutions (which are no longer applied in modern shearers). Motors driving the cutting heads are located in the frame, which requires the use of a so-called wet joint for transmitting the torque by the arm axis of rotation. Additionally, the motor axis is perpendicular to the axis of the cutting head, which requires the application of an intersecting axis gear. Moreover, the PMAP shearer can also be installed in a version with one cutting head. The PMAP shearer is designed for work in walls with thicknesses ranging from $1.25 \mathrm{~m}$ to $2.50 \mathrm{~m}$. The output of the cutting head drive is $2 \times 120 \mathrm{~kW}$.

The Mackina RPB60 and PMA80 models are twohead and two-arm shearers with a chain haulage system that are intended for direct work on floors in walls characterized by high longitudinal slopes within a range of $35^{\circ}$ to $85^{\circ}$. In both shearers, the 
same arrangement of the frame, arms with cutting heads, haulage arm, and winch has been applied. The RPB60 shearer (Fig. 7) cuts ultra-thin seams with thicknesses ranging from $0.38 \mathrm{~m}$ to $0.85 \mathrm{~m}$, with the output of the cutting head motors of $2 \times 30 \mathrm{~kW}$. On the other hand, the PMA 80 cuts thin and medium seams with thicknesses within a range of $1.10 \mathrm{~m}$ to $2.5 \mathrm{~m}$ and with a cutting head output of $2 \times 120 \mathrm{~kW}$. In both shearers, the motors driving the cutting heads are mounted in the frame, but their axles are parallel; this simplifies the transmission of torque.

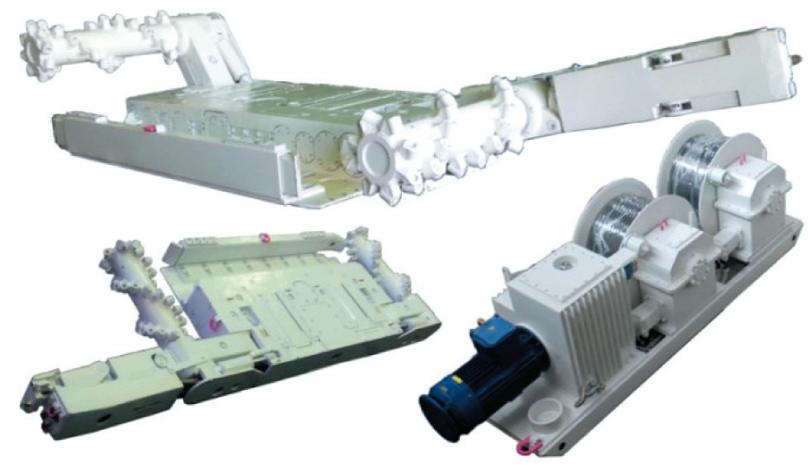

Fig. 7. RPB60 two-head cutting shearer produced by Mackina for thin seams, and winch

An example of unique construction is the Mackina TEMP-H shearer (Fig. 8), which has two cutting heads but only one arm as well as a chain haulage system. It is designed to work directly on a floor in thin seams with high longitudinal slopes within a range of $30^{\circ}$ to $85^{\circ}$. Its uniqueness is visible in the solutions applied, which are different than those found in the remaining shearers for inclined seams. This shearer is equipped with one electric motor with an output of $80 \mathrm{~kW}$, which drives the lower cutting head (first) by a hydrostatic torque converter (pump-motor), whereas the upper head (second) is driven from the lower cutting head by means of a chain begirding the arm. The chain has both driving and cutting functions, so it is equipped with picks. Application of conical picks on the cutting heads while the chain has been equipped with radial tools is also atypical.
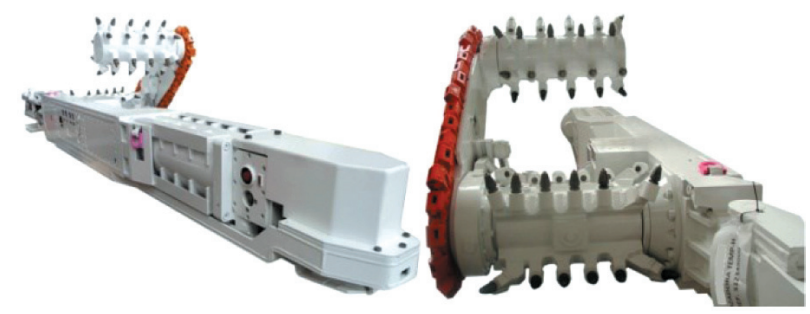

Fig. 8. TEMP-H two-head shearer for thin seams produced by Mackina
Beijing HOT Mining Tech Co., Ltd. (hereinafter referred to as HOT) is a supplier of products and services for mining and mineral processing. It offers machines produced by four external companies belonging to the group of Original Equipment Manufacturers (so-called OEM), which means that only HOT puts its name on these products. It does not change the fact that longwall shearers offered by HOT are worth quoting.

The HMG100/250-PBD HOT two-arm, two-head shearer is also characterized by classic construction and moves along a conveyor, but it is not equipped with tractors. The drives of its chain haulage system are located in the headings.

Another solution offered by HOT is a one-arm, one-head cutting shearer with a chainless haulage system, the three models of which form the HMG series. These shearers move in a traditional way along a conveyor using one tractor and double frame saw wheels in a popular system called Eicotrack (Fig. 9). The HMG shearers are equipped with cutting head motors with outputs of $100 \mathrm{~kW}, 100 \mathrm{~kW}$, and $120 \mathrm{~kW}$, respectively, and are designed to cut walls with heights ranging from 0.75 to $1.2 \mathrm{~m}$.

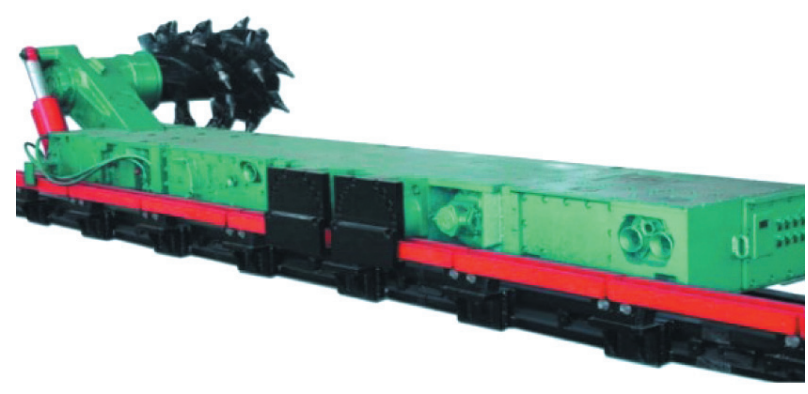

Fig. 9. HMG100/111-TWD one-head cutting shearer for thin seams produced by HOT

The last discussed solution is the HMG100-TP shearer offered by HOT, which has a one-head armless construction with a chain haulage system for direct work on a floor; it is intended for highly inclined seams (Fig. 10). Unlike the remaining shearers of this type, this shearer loads coal onto the face conveyor by means of a short chain conveyor, which transports the mined rock directly from the cutting head area. The shearer does not have a haulage drive installed in the frame and requires the use of a winch. Depending on the diameter of the cutting head driven by a motor with an output of $100 \mathrm{~kW}$, the shearer is designed for work in longwalls with thicknesses ranging from 0.44 to $0.9 \mathrm{~m}$. 


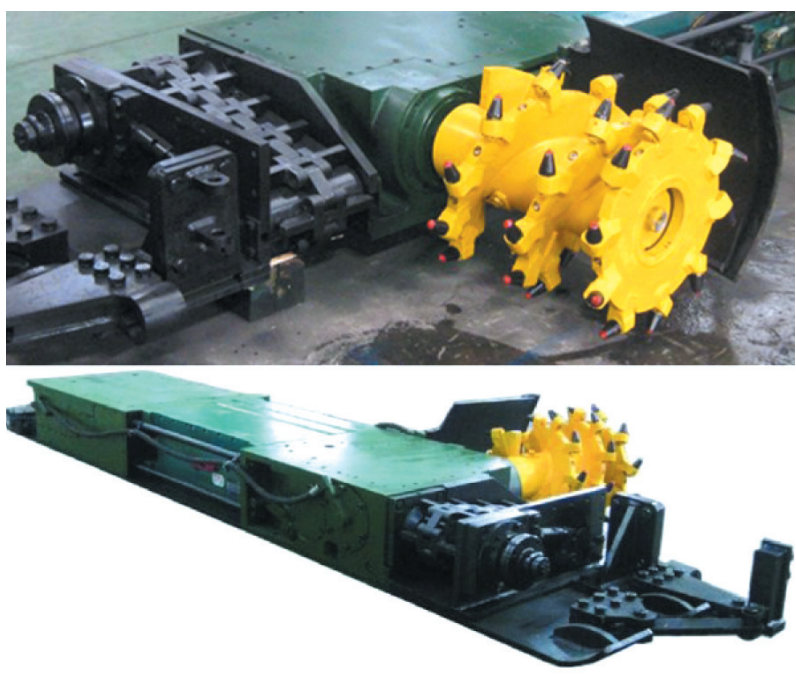

Fig. 10. HMG100-TP one-head cutting shearer for ultra-thin seams offered by HOT

\section{ONE-HEAD SHEARER FOR CUTTING ULTRA-THIN SEAMS}

Despite the considerable differences in the construction of longwall cutting shearers and static coal plows, the key problems related to the increasing of daily output still remain unsolved [14]. The solution that allows for achieving a satisfactory daily output in longwalls with heights ranging from 1.0 to $1.6 \mathrm{~m}$ (which is economically justified under Polish conditions) is a longwall system equipped with a one-head shearer. The one-head cutting shearer combines the advantages of plowing and cutting-loading technology while eliminating their basic drawbacks. The said solution has been developed at AGH and offers a promising alternative to the currently used longwall systems.

Figure 11 presents one-head cutting shearer (I) mounted on face conveyor (II). According to the assumptions, the shearer consists of frame (1), whose main assembly is the driving unit (2) with a milling spatial head mounted on the shaft end (3).

Loaders are fixed to the frame by means of the arms (4) and cylinders (5). The first loader (6) is in the active position, whereas the second (7) is in the passive one. The frame has two caving skids (8) and two sidewall skids (9). The caving skids (8) are connected with the drive chain (13). The frame from the caving side has a cable handler grip (11) with cables. Each loader is equipped with rolls (10) that prevent it from getting blocked on rough surfaces. The cables are placed in the cable handler (11) and are guided in the gate (12). Shearer I is drawn by means of the chain (13). The sidewall skid of the shearer (9) moves along the conveyor's sidewall guide (15), whereas the caving skid (8) moves along the conveyor's caving guide (14). The system has been equipped with a hydraulic cylinder for vertical horizon control (16).

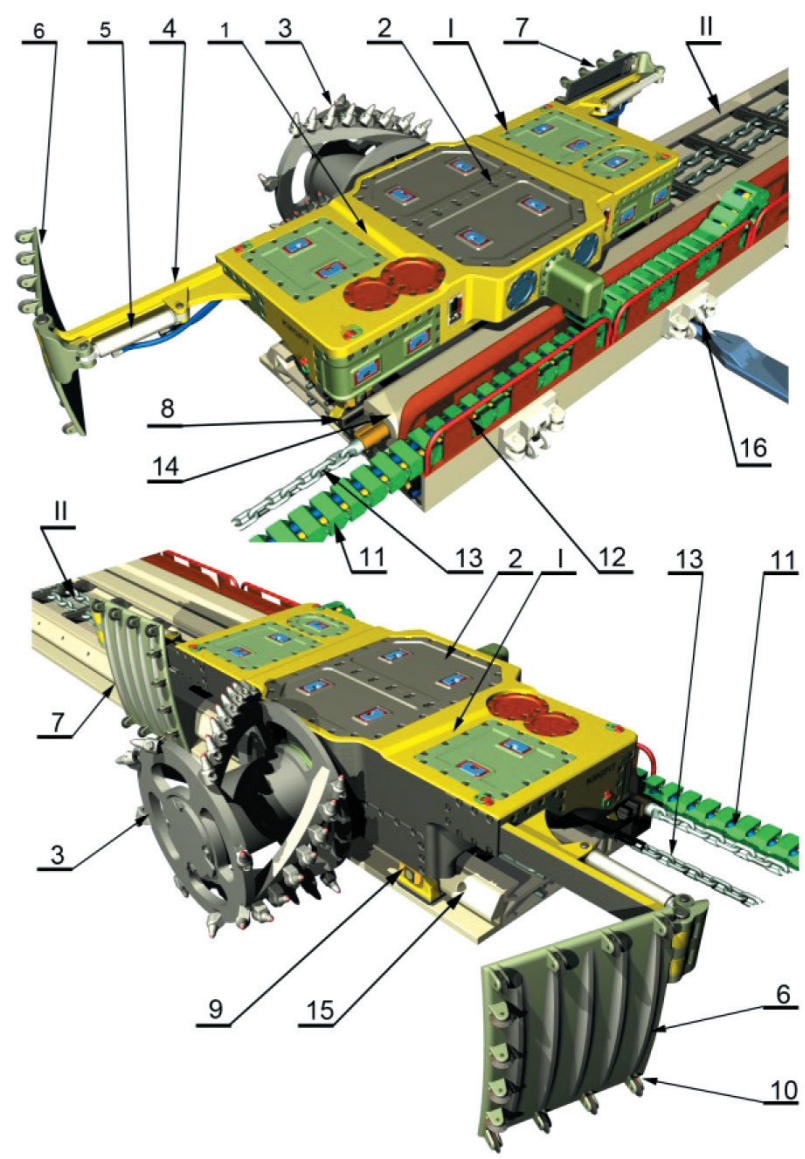

Fig. 11. Solution of one-head cutting shearer on face conveyor developed by $A G H$

Such a solution enables the effective exploitation of seams owing to work in a two-way mining longwall system as well as the application of cutting, separating the cutting process from the loading process, using full work automation, implementing a chain haulage system, and creating possibilities to start a new sequence of cutting without sumping $[14,15]$.

\section{SUMMARY}

Producers of mining machines in Poland and abroad offer many types of cutting shearers and coal plows designed to work in mechanized longwall systems. The solutions available in various countries (especially in the case of shearers) differ from classic 
construction; this is caused by the local natural and economic conditions. The review and division of longwall shearers presented in this article draws attention to the multitude of solutions. The reason for such a situation is the constant search for machines dedicated to particular specific conditions as well as ever-growing technical possibilities, especially the development of automation (which allows for eliminating man from particularly dangerous areas).

The presented currently applied longwall shearers frequently enable only several hundred tons of daily output to be obtained from a face, which is not acceptable under Polish conditions.

In global solutions, apart from machines included in longwall shearer systems, also mining machines designed for other methods and systems of exploitation are applied $[4,5]$.

The conceptual and prospective solution proposed by AGH (a system for thin-seam exploitation) is equipped with a one-head cutting shearer designed to work in two-way mining technology. A characteristic feature of this technology is, in this case, the lack of the sumping phase and full web work over the whole length of the face. Application of a cutting head allows for a positive evaluation of the possibility to implement such a shearer for work in seams with disturbances and coals characterized by the highest machinability index. Resignation from loading by means of machine cutting heads and withdrawing the staff from the face eliminates the major limitations of classic shearing technology.

\section{Acknowledgements}

The works were carried out within the framework of the Dean Grant under agreement no. 15.11.130.838.

\section{References}

[1] Beijing HOT Mining Tech Co., Ltd, www.hotmining.cn [22.05.2018].

[2] Mackina-Westfalia S.A., www.mackina-westfalia.com [20.03.2018].

[3] Corum Group, www.corum.com [22.05.2018].

[4] Kotwica K., Mendyka P., Bołoz Ł. et al.: Wybrane problemy urabiania, transportu i przeróbki skat trudnourabialnych, t. 1, red. K. Krauze, Wydawnictwa AGH, Kraków 2016.

[5] Bołoz Ł., Maszyny urabiające $w$ wybranych metodach eksploatacji cienkich pokładów węla kamiennego, "Systemy Wspomagania w Inżynierii Produkcji, Górnictwo - Perspektywy i Zagrożenia: Węgiel, Tania Czysta Energia i Miejsca Pracy" 2018, 7, 1: 131-142.

[6] Bołoz Ł.: Maszyny urabiające $w$ ścianowych systemach eksploatacji cienkich pokładów węgla kamiennego, "Systemy Wspomagania w Inżynierii Produkcji, Górnictwo - Perspektywy i Zagrożenia: Węgiel, Tania Czysta Energia i Miejsca Pracy" 2018, 7, 1: 143-154.

[7] Jaszczuk M.: Ścianowe systemy mechanizacyjne, Wydawnictwo "Śląsk", Katowice 2007.

[8] Krauze K.: Urabianie skat kombajnami ścianowymi, Wydawnictwo "Śląsk", Katowice 2000.

[9] Krauze K.: Urabianie skat strugami statycznymi, Wydawnictwo "Śląsk", Katowice 2012.

[10] Piechota S.: Podstawowe zasady i technologie wybierania kopalin stałych, Biblioteka Szkoły Eksploatacji Podziemnej, Kraków 2003.

[11] KOPEX S.A., www.kopex.com.pl [22.05.2018].

[12] Famur S.A., www.famur.com.pl [22.05.2018].

[13] Eickhoff Bergbautechnik GmbH, www.eickhoff-bochum.de [22.05.2018].

[14] Bołoz Ł.: Ocena obciażenia jednoorganowego kombajnu ścianowego na podstawie badań analitycznych, AGH w Krakowie, Kraków 2012 [PhD thesis].

[15] Bołoz Ł.: Kombajnowy kompleks ścianowy przeznaczony do pracy w niskich ścianach, "Przegląd Górniczy" 2016, 72, 6: 91-97.

ŁUKASZ BOŁOZ, Ph.D., Eng. Department of Mining, Dressing and Transport Machines

Faculty of Mechanical Engineering and Robotics AGH University of Science and Technology al. Mickieiwcza 30, 30-059 Krakow, Poland boloz@agh.edu.pl 


\title{
Kombajny ścianowe do eksploatacji cienkich oraz cienkich i silnie nachylonych pokładów węgla kamiennego
}

\begin{abstract}
Zmechanizowane kompleksy ścianowe ze względu na ich wiele zalet stosowane sq do eksploatacji pokładów z dużej rozpiętości miąższości. W przypadku pokładów cienkich oraz cienkich i silnie nachylonych można wyróżnić wiele odmiennych rozwiazań kombajnów ścianowych pozwalających na eksploatację wegla z pokładów o grubości od $0,4 \mathrm{~m}$ i przy nachyleniu podtużnym do $85^{\circ}$. W artykule skupiono się na ścianowych systemach eksploatacji tych pokładów. Przedstawiono najważniejsze zatożenia i zalety eksploatacji ścianowej oraz omówiono stosowane maszyny urabiające stanowiace kluczowy element ścianowych systemów mechanizacyjnych. Zwrócono również uwage na rozwiazania kombajnów, które obecnie nie sa stosowane na rynku krajowym. Szeroka gama dostępnych rozwiąań pozwoliła wyróżnić i zaprezentować dziesięć typów kombajnów.
\end{abstract}

Słowa kluczowe: cienkie pokłady, pokłady nachylone, mechanizacja górnictwa, systemy ścianowe, kombajny ścianowe

\section{WSTĘP}

Pozyskiwanie minerałów ze złóż rozpoczyna się od tych najatrakcyjniejszych $\mathrm{w}$ aspekcie opłacalności oraz trudności technicznych. W szczególności ma to znaczenie dla eksploatacji podziemnej. W przypadku węgla kamiennego zalegającego w postaci pokładów bardzo często, dopóki nie ma takiej konieczności, pomijane są pokłady cienkie i silnie nachylone. Jednak w wielu krajach obserwuje się rosnące zainteresowanie tymi pokładami. Zainteresowanie to wynika w dużej mierze z ich znacznej ilości oraz konieczności racjonalnego wykorzystania dostępnych źródeł energii. Szczególnie w ostatnich latach coraz więcej uwagi poświęca się możliwości opłacalnej ekonomicznie eksploatacji cienkich i nachylonych pokładów. W przypadku Polski pokładami cienkimi możemy nazwać te o miąższości od 1,0 m, jednak w niektórych krajach wybiera się pokłady znacznie cieńsze, nawet od $0,4 \mathrm{~m}$. Natomiast za górną granicę można przyjąć 1,6 m. Powyżej 1,6 m zastosowanie klasycznej techniki kombajnowej lub w korzystnych warunkach strugowej nie przysparza problemów typowych dla niskich wyrobisk.

Najważniejszym elementem zmechanizowanego systemu ścianowego jest maszyna urabiająca. Maszyną urabiającą może być kombajn ścianowy albo statyczny strug węglowy. Pomimo stosowania dwóch rodzajów maszyn wybór dostępnych rozwiązań jest bardzo szeroki. Analizując dostępne obecnie na całym świecie rozwiązania, zwłaszcza w przypadku kombajnów ścianowych, można stwierdzić, że poszczególne typy różnią się od siebie w istotny sposób.

\section{SYSTEMY DLA ŚCIAN NISKICH I SILNIE NACHYLONYCH}

Zaleganie węgla kamiennego w postaci pokładu, niezależnie od jego grubości, decyduje o sposobie jego eksploatacji. Najkorzystniejszym, pozwalającym na wysokie wykorzystanie złoża, sposobem wybierania pokładu jest eksploatacja ścianowa kompleksem zmechanizowanym. W artykule skupiono się na 
omówieniu różnych rozwiązań kombajnów ścianowych stanowiących maszynę urabiającą w kompleksie. Przedstawiono kombajny stosowane w Polsce oraz niespotykane na naszym rynku. W szczególności dotyczy to kombajnów do pokładów cienkich chińskiej firmy Beijing HOT Mining Tech Co., Ltd. [1], kombajnów do pokładów cienkich i jednocześnie silnie nachylonych hiszpańskiego przedsiębiorstwa Mackina-Westfalia S.A. [2] oraz kombajnu firmy CorumGroup [3]. Wszystkie dostępne produkty firm posiadających w swojej ofercie klasyczne i obecnie najczęściej stosowane kombajny ścianowe oraz statyczne strugi węglowe zostały wraz z parametrami technicznymi omówione w książce [4]. Natomiast informacje w zakresie rozwiązań nietypowych, stosowanych w specyficznych warunkach można znaleźć w artykułach $[5,6]$.

Eksploatacja systemem ścianowym polega na rozcięciu pokładu węgla chodnikami i połączeniu dwóch chodników przecinką ścianową o długości $L$ odpowiadającej długości ściany i wysokości $H$ zbliżonej do miąższości pokładu. Ściana może być nachylona podłużnie pod kątem $\alpha$. Wyrobiska te tworzą przodek wydobywczy (rys. 1). Ściana udostępniona dwoma chodnikami zapewnia przewietrzanie, możliwość sprawnego transportu oraz odstawy urobku. Obecnie wyrobisko ścianowe zostaje wyposażone w kombajnowy lub strugowy kompleks ścianowy, które jak technologia ścianowa są znane i opisane w literaturze [7-10].

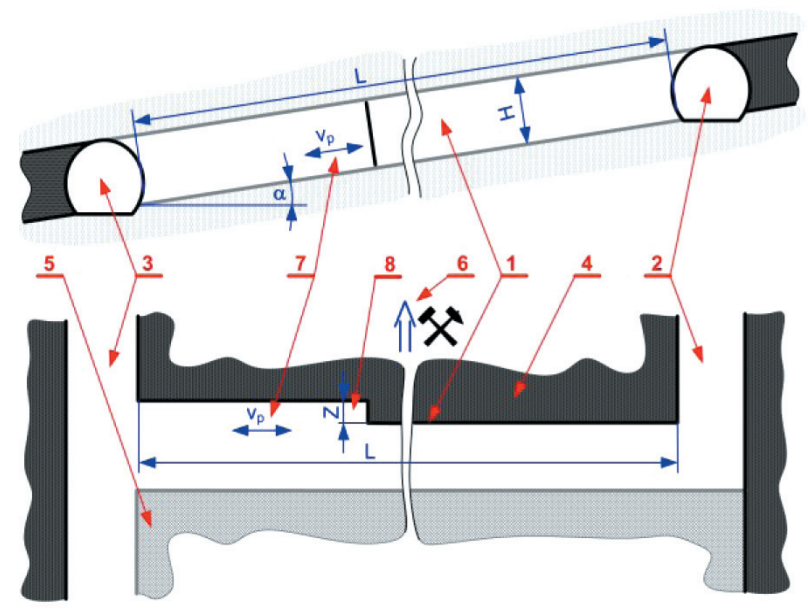

Rys. 1. Schemat wyrobiska ścianowego: 1 - czoło ściany, 2 - chodnik nadścianowy, 3 - chodnik podścianowy, 4 - calizna węglowa, 5 - zroby, 6- kierunek eksploatacji, 7- kierunek urabiania maszyny, 8-wykonywany zabiór caliźnie weglowej, $v_{p}$ - prędkość posuwu kombajnu, $a$ - kąt nachylenia podtużnego ściany, $H$ - wysokość ściany, $L$ - dtugość ściany, Z - zabiór
Zmechanizowany kompleks ścianowy wyposażony w maszynę urabiającą, przenośnik ścianowy oraz zmechanizowaną obudowę ścianową umożliwia realizacje procesu urabiania calizny i ładowania oraz odstawy urobku ze ściany. Kompleksy ścianowe różnią się w zależności od wysokości i długości ściany, nachylenia pokładu oraz warunków górniczo-geologicznych. Maszyna urabiająca porusza się z prędkością $v_{p}$ i urabia caliznę na głębokość zabioru $Z$. Urabianie może odbywać się $\mathrm{w}$ jednym lub w obu kierunkach. Urabianie dwukierunkowe jest najbardziej efektywne, natomiast jednokierunkowe wskazane jest w przypadku problemów z urabianiem lub ładowaniem urobku.

Systemy mechanizacyjne stosowane w pokładach silnie nachylonych często odbiegają od klasycznych kombajnowych systemów ścianowych i warto krótko przybliżyć te różnice. W praktyce ze względu na zmienność warunków zarówno systemy te, jak i maszyny są każdorazowo dostosowywane do lokalnych warunków i mogą się od siebie znacznie różnić. Wyposażenie kompleksu w przypadku ścian o podłużnym nachyleniu w zakresie od $30^{\circ}$ do $85^{\circ}$ składa się jedynie $\mathrm{z}$ kombajnu oraz obudowy zmechanizowanej. Natomiast przenośnik zgrzebłowy zlokalizowany jest w chodniku odstawczym poniżej zsypów. Charakterystyczną cechą zastosowanego kombajnu jest brak zabudowanego napędu posuwu oraz poruszanie się bezpośrednio po spągu, czyli bezpośredni kontakt płyty ślizgowej kombajnu ze spągiem. Kombajn ciągnięty jest dwulinowym kołowrotem, $\mathrm{z}$ jedną liną awaryjną. Prowadzenie wzdłuż eksploatowanej ściany zapewniają ślizgi kombajnu zabudowane od strony zrobów i współpracujące $z$ belkami ślizgowymi, które połączone sa $\mathrm{z}$ mechanizmem przesuwu sekcji obudowy. Kombajn urabia ścianę podczas ruchu w kierunku chodnika nadścianowego. Urobek ze względu na duże nachylenie stacza się samoczynnie w kierunku chodnika odstawczego. Po zakończeniu skrawu i podciągnięciu obudowy kombajn opuszczany jest w kierunku wnęki, gdzie rozpoczyna się kolejny skraw [7]. Oprócz kombajnów frezujących w ścianach silnie nachylonych zastosować można kompleksy strugające [3, 4].

\section{FREZUJACE KOMBAJNY ŚCIANOWE}

Niezależnie od miąższości pokładu najpopularniejszymi obecnie produkowanymi kombajnami ścianowymi są klasyczne, dwuramionowe, dwuorganowe 
maszyny poruszające się po przenośniku za pomocą bezcięgnowego systemu posuwu. Stosowane w Polsce kombajny ścianowe można podzielić na trzy typy:

- dwuramionowe, dwuorganowe, $z$ bezcięgnowym systemem posuwu, z kadłubem nad przenośnikiem (rys. 2a);

- dwuramionowe, dwuorganowe, $\mathrm{z}$ bezcięgnowym systemem posuwu, $\mathrm{z}$ kadłubem prowadzonym obok przenośnika (rys. 2b);

- bezramionowy, dwuorganowy z cięgnowym systemem posuwu (rys. 2c) [5, 11].

Odnosząc się jednak do stanu techniki na świecie, należy jeszcze zwrócić uwagę na następujące typy kombajnów:

- dwuorganowy, dwuramionowy z cięgnowym systemem posuwu;

- jednoramionowy, jednoorganowy $\mathrm{z}$ bezcięgnowym systemem posuwu;

- bezramionowy, jednoorganowy AGH (koncepcja) (rys. 2d);

- bezramionowy, dwuorganowy z pionowymi osiami organów (rys. 2e);

- dwuorganowy, dwuramionowy z cięgnowym systemem posuwu do bezpośredniej pracy na spągu (rys. 2f);

- jednoramionowy, dwuorganowy, z cięgnowym systemem posuwu do bezpośredniej pracy na spagu (rys. $2 \mathrm{~g}$ );

- bezramionowy, jednoorganowy, z cięgnowym systemem posuwu do bezpośredniej pracy na spagu (rys. 2h).

W ujęciu historycznym w górnictwie zarówno światowym, jak i polskim, stosowane były maszyny o innych konfiguracjach organów oraz rodzajach napędów. W aspekcie cienkich pokładów rozwiązania nietypowe, które stosowane są dla szczególnych warunków, na przykład dużych nachyleń czy ultracienkich pokładów nie występują w Polsce. Oprócz najbardziej znanych kombajnów jako przykłady interesujących rozwiązań przytoczone zostaną przykładowe maszyny urabiajace $\mathrm{z}$ oferty wspomnianych firm Mackina-Westfalia S.A., Beijing HOT Mining Tech Co., Ltd. oraz CORUM Group. Natomiast szczegółowe dane oraz pozostałe modele można znaleźć w podanej literaturze oraz w katalogach producentów.

Polska firma Kopex Machinery S.A. [11] została założona w 1961 roku i znana jest $\mathrm{z}$ produkcji maszyn górniczych, a zwłaszcza kombajnów ścianowych.
Obecnie firma Kopex Machinery wraz $\mathrm{z}$ grupa KOPEX zależna jest od firmy FAMUR S.A [12]. Kombajn KSW-460NE1 (rys. 3) firmy Kopex Machinery jest kombajnem ścianowym wąskoramionowym, z elektrycznym napędem posuwu, poruszającymi się po przenośniku. Posiada dwa ramiona i dwa organy. Cechy te są typowe dla klasycznych kombajnów stosowanych do pokładów średnich i grubych. Kombajn Kopex KSW-460NE1 wyposażony jest w system sterowania z pamięcią skrawu współpracujący z nadrzędnym systemem sterowania kompleksu ścianowego. Przeznaczony jest do urabiania węgla w ścianach w zakresie wysokości od 1,35 m do 2,4 m. Charakteryzuje się mocą organów $2 \times 200 \mathrm{~kW}$.

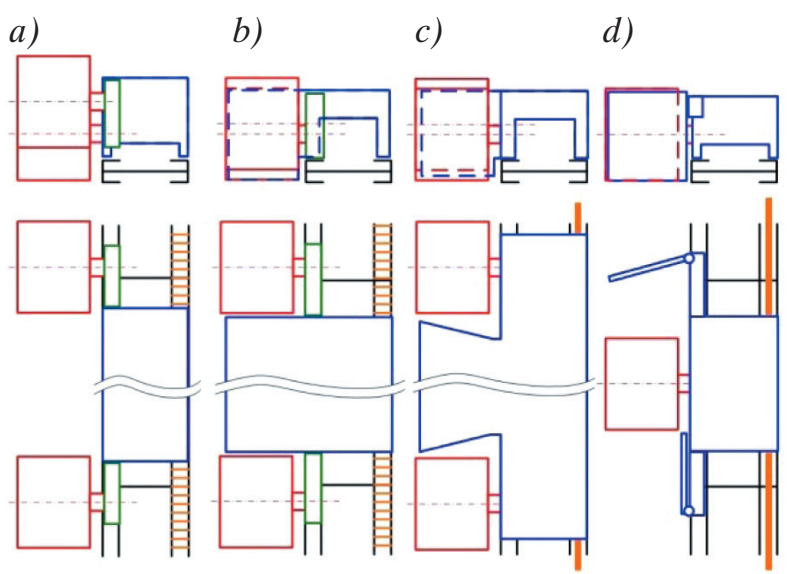

e)

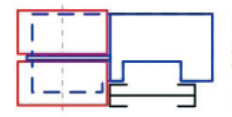

f)

g)

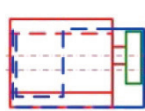

h)
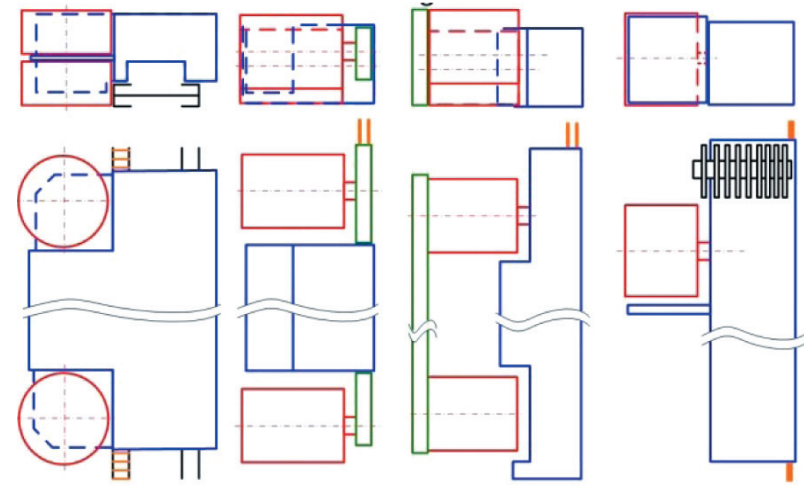

Rys. 2. Schematy wybranych typów kombajnów ścianowych do cienkich i nachylonych poktadów: (niebieski kadtub, czerwony - organ, czarny - przenośnik, zielony ruchome ramię organu, pomarańczowy - system posuwu): a) dwuramionowy, dwuorganowy na przenośniku; b) dwuramionowy, dwuorganowy obok przenośnika; c) bezramionowy, dwuorganowy; d) bezramionowy, jednoorganowy AGH; e) bezramionowy, dwuorganowy z osiami pionowymi; f) dwuramionowy, dwuorganowy po spagu; g)jednoramionowy, dwuorganowy; $h$ ) bezramionowy, jednoorganowy z przenośnikiem 


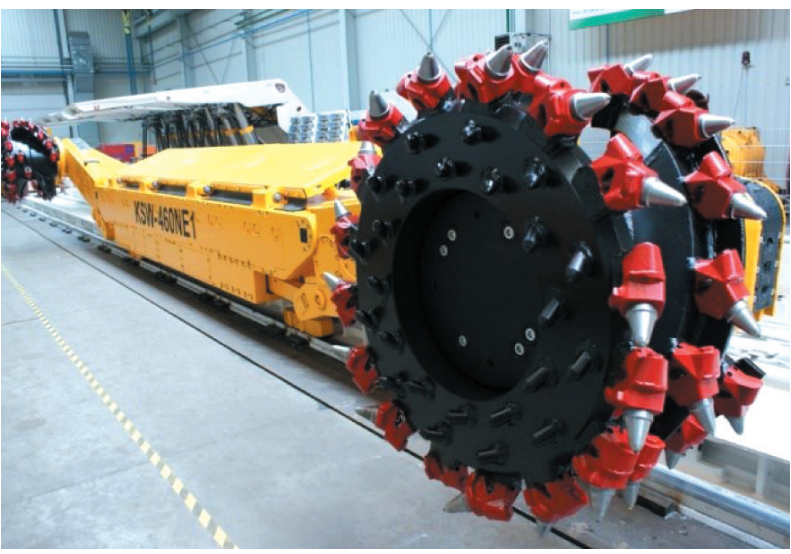

Rys. 3. Kombajn ścianowy KSW-460NE1 firmy Kopex Machinery

Niemiecka firma Eickhoff Bergbautechnik GmbH [13] została założona w 1864 roku i znana jest przede wszystkim z produkcji kombajnów ścianowych. Eickhoff posiada w ofercie jeden kombajn, którego wysokość urabiania częściowo pokrywa się z zakresem miąższości pokładów cienkich. Jest to kombajn ścianowy SL $300 \mathrm{~L}$ przeznaczony do pracy w ścianach o wysokościach od 1,2 m do 2,0 m (rys. 4).

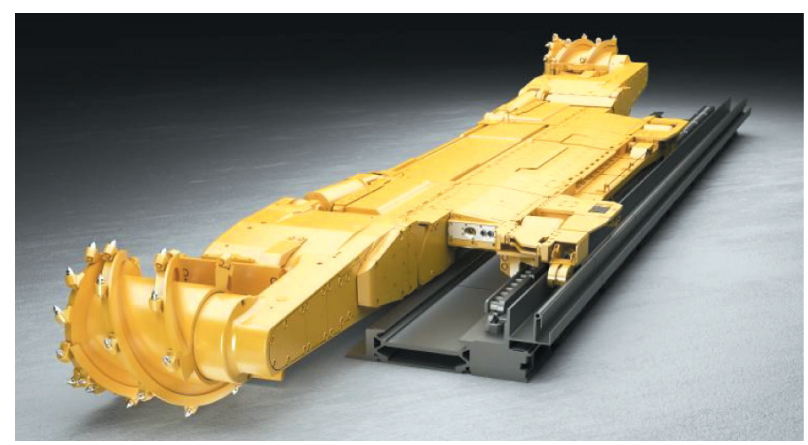

Rys. 4. Kombajn ścianowy SL 300 L firmy Eickhoff

Kombajn SL 300 L charakteryzuje się dwuramionową, dwuorganową konstrukcją. Wyposażony jest w bezcięgnowy system posuwu, a jego kadłub porusza się obok przenośnika. W przeciwieństwie do konkurencji, siłowniki podnoszenia ramion zabudowano nad kadłubem. Kombajn wyposażono w napęd organów $2 \times 300 \mathrm{~kW}$.

Unikatowym rozwiązaniem firmy Kopex jest kompleks Mikrus (rys. 5) z głowicą urabiająco-ładującą GUŁ-500 przeznaczony do dwukierunkowego, bezwnękowego urabiania i ładowania węgla w cienkich pokładach. Zakres wysokości urabiania zależy od średnicy zastosowanego organu urabiającego i wynosi od 1,1 m do 1,7 m. Kombajn GUŁ-500 umożliwia zmianę wysokości urabiania w ograniczonym zakre- sie, jednak zmiana odbywa się przy zatrzymanej maszynie. Głowica urabiająco-ładująca przemieszczana jest wzdłuż ociosu węglowego za pomocą cięgnowego systemu posuwu typu strugowego, który napędzany jest elektrycznymi silnikami zasilanymi z przemienników częstotliwości umieszczonych w chodnikach. Kombajn charakteryzuje się dwuorganową, bezramionową konstrukcją. Oba organy są sprzężone mechanicznie i napędzane z jednego silnika o mocy $500 \mathrm{~kW}$.

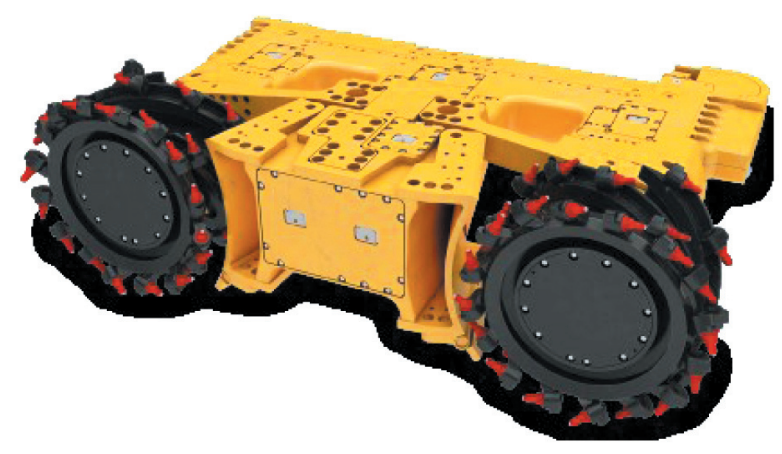

Rys. 5. Kombajn Mikrus, GU屯-500 firmy Kopex Machinery

Ukraińska firma CorumGroup została założona w 1889 roku i oferuje maszyny górnictwa podziemnego. Firma Corum posiada w swojej ofercie kombajn KBT200 (rys. 6). Jest to wyjątkowe rozwiązanie kombajnu ścianowego, gdyż porusza się on po przenośniku za pomocą bezcięgnowego systemu posuwu. Cechą charakterystyczną jest konstrukcja bezramionowa oraz obrócone o $90^{\circ}$ osie organów. Pionowe osie umożliwiają łatwiejsze urabianie i ładowanie urobku na przenośnik. Kombajn KBT200 przeznaczony jest do wybierania węgla zalegającego w pokładach o miąższości od $0,8 \mathrm{~m}$ do 1,25 m.

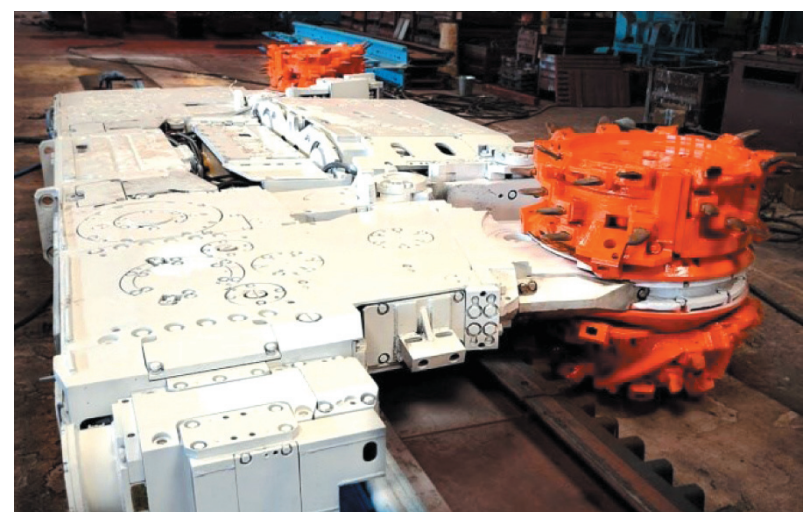

Rys. 6. Kombajn ścianowy firmy Corum typu KBT200

Firma Mackina-Westfalia S.A. rozpoczęła działalność w 1955 roku. Zajmowała się projektowaniem 
i produkowaniem między innymi maszyn górniczych. W roku 1994 Mackina uniezależniła się od niemieckiej firmy Westfalia Lünen, nie zmieniając przy tym profilu swojej działalności.

Kombajn dwuramionowy, dwuorganowy z bezcięgnowym systemem posuwu PMAP Mackina charakteryzuje się klasyczną konstrukcją i porusza się po przenośniku, jednak ze względu na cechy konstrukcyjne i zastosowane rozwiązania niespotykane już we współczesnych kombajnach zostanie przybliżony. Silniki napędzające organy zlokalizowane są w kadłubie, co wymaga zastosowania tak zwanego przegubu mokrego do przekazania momentu przez oś obrotu ramienia. Dodatkowo oś silnika jest prostopadła do osi organu, co wymaga zastosowania przekładni kątowej. Ponadto kombajn PMAP może również zostać zabudowany $\mathrm{w}$ wersji $\mathrm{z}$ jednym organem urabiającym. Kombajn PMAP przeznaczony jest do pracy w ścianach od 1,25 m do 2,50 m. Moc napędu organów wynosi $2 \times 120 \mathrm{~kW}$.

Modele Mackina RPB60 oraz PMA80 są kombajnami dwuorganowymi i dwuramionowymi z cięgnowym systemem posuwu i przeznaczone są do bezpośredniej pracy na spągu w ścianach o dużym nachyleniu podłużnym, w zakresie $35-85^{\circ}$. W obu kombajnach zastosowano ten sam układ korpusu, ramion $\mathrm{z}$ organami, ramienia ciągnącego oraz kołowrotu. Kombajn RPB60 (rys. 7) urabia pokłady ultracienkie od $0,38 \mathrm{~m}$ do $0,85 \mathrm{~m}$ przy mocy silników organów $2 \times 30 \mathrm{~kW}$. Natomiast PMA80 urabia pokłady cienkie do średnich, od 1,10 $\mathrm{m}$ do 2,5 $\mathrm{m}$ przy napędzie organów $2 \times 120 \mathrm{~kW}$. W obu kombajnach silniki napędzające organy zabudowane są w kadłubie, jednak ich osie są równoległe, co upraszcza przekazanie momentu.

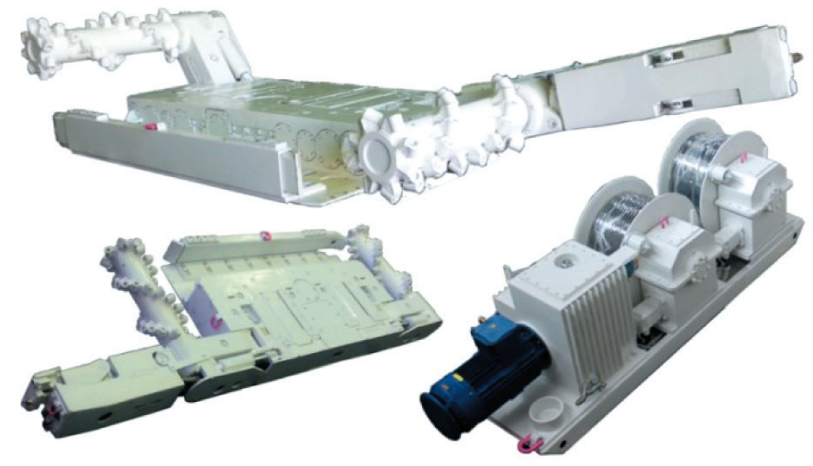

Rys. 7. Dwuorganowy kombajn RPB60

firmy Mackinado cienkich pokładów oraz kołowrót

Niezwykłą konstrukcją jest kombajn Mackina TEMP-H (rys. 8), który jest dwuorganowy, ale jednoramionowy, z cięgnowym systemem posuwu i przezna- czony jest do pracy bezpośrednio na spągu w cienkich pokładach silnie nachylonych podłużnie w zakresie $30 \div 85^{\circ}$. Za jego wyjątkowością przemawiają zastosowane rozwiązania odróżniające go od pozostałych kombajnów do pokładów nachylonych. Kombajn ten wyposażony jest $\mathrm{w}$ jeden silnik elektryczny o mocy $80 \mathrm{~kW}$, który przez przekładnię hydrostatyczną (pompa-silnik) napędza organ dolny (pierwszy). Natomiast organ górny (drugi) napędzany jest $z$ organu dolnego przez łańcuch opasający ramię. Łańcuch pełni jednocześnie funkcję napędową oraz urabiającą, w związku z tym zbrojony jest nożami. Zastosowanie noży styczno-obrotowych do zbrojenia organów przy wykorzystaniu noży promieniowych do zbrojenia łańcucha jest również nietypowe.

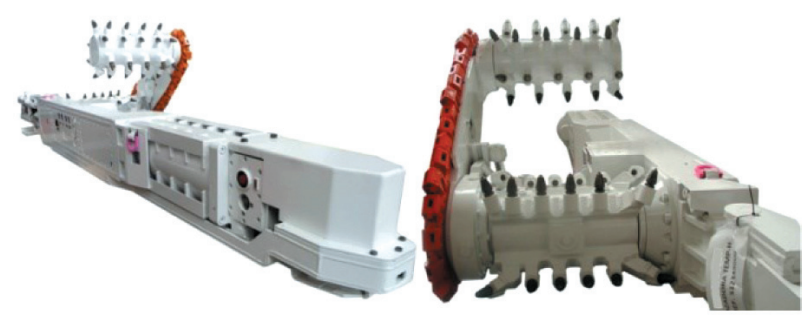

\section{Rys. 8. Dwuorganowy kombajn TEMP-H}

firmy Mackinado cienkich pokładów

Firma Beijing HOT Mining Tech Co., Ltd (dalej HOT) jest dostawcą produktów i usług dla górnictwa i przeróbki kopalin. Oferuje maszyny produkowane przez cztery firmy zewnętrzne typu Original Equipment Manufacturer (tzw. OEM), czyli HOT jedynie firmuje te produkty. Co nie zmienia faktu, że informacja o oferowanych przez HOT kombajnach ścianowych jest warta przytoczenia.

Kombajn dwuorganowy, dwuramionowy HMG100/ 250-PBD HOT również charakteryzuje się klasyczną konstrukcją i porusza się po przenośniku, jednak nie jest wyposażony w ciągniki, a jego napędy cięgnowego systemu posuwu znajdują się w chodnikach.

Kolejne rozwiązanie firmy HOT stanowią kombajny jednoramionowe, jednoorganowe $\mathrm{z}$ bezcięgnowym systemem posuwu, których trzy modele tworzą serię HMG. Kombajny te klasycznie poruszają się po przenośniku z zastosowaniem jednego ciągnika oraz podwójnych kół trakowych w popularnym systemie typu Eicotrack (rys. 9). Kombajny HMG wyposażono silniki organów o mocy kolejno 100 kW, 100 kW, 120 kW i przeznaczone są do eksplantacji ścian o wysokości w zakresie od $0,75 \mathrm{~m}$ do $1,2 \mathrm{~m}$. 


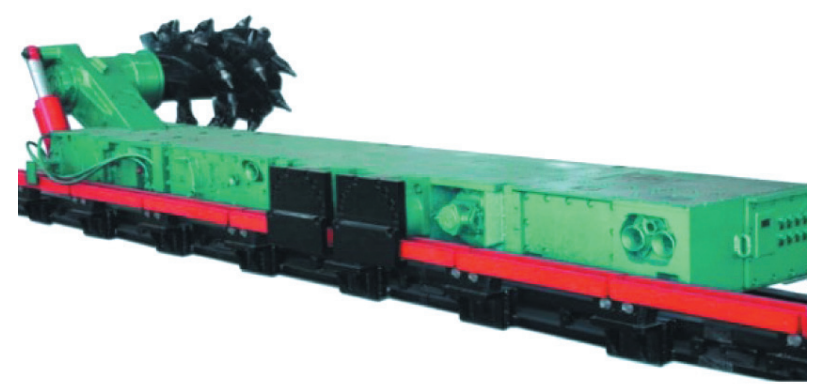

Rys. 9. Jednoorganowy kombajn HMG100/111-TWD firmy HOT do cienkich pokładów

Ostatnim omawianym kombajnem jest konstrukcja jednoorganowa, bezramionowa z cięgnowym systemem posuwu do bezpośredniej pracy na spągu, do pokładów silnie nachylonych HMG100-TP firmy HOT (rys. 10). W odróżnieniu od pozostałych kombajnów tego typu, ten kombajn ładuje na przenośnik ścianowy za pomocą krótkiego przenośnika zgrzebłowego odprowadzającego urobek bezpośrednio z okolicy organu. Kombajn nie posiada zabudowanego w kadłubie napędu posuwu i wymaga zastosowania kołowrotu. Kombajn w zależności od średnicy organu, napędzanego silnikiem o mocy $100 \mathrm{~kW}$, przeznaczony do pracy w ścianach od 0,44 m do $0,9 \mathrm{~m}$.

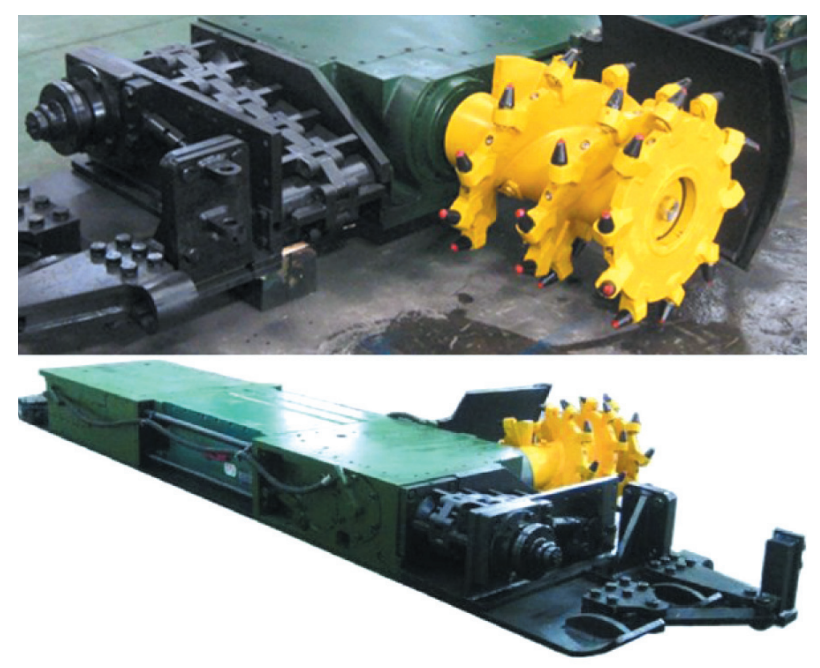

Rys. 10. Jednoorganowy kombajn HMG100-TP firmy HOT do ultracienkich pokładów

\section{KOMBAJN JEDNOORGANOWY DO CIENKICH POKŁADÓW}

Pomimo dużego zróżnicowania konstrukcji kombajnów ścianowych oraz statycznych strugów węglowych nadal nie rozwiązano kluczowych problemów pozwalających na zwiększenie wydobycia dobowego [14]. Rozwiązaniem pozwalającym na osiągnięcie zadowalającego, ekonomicznie uzasadnionego w polskich warunkach, wydobycia dobowego w ścianach o wysokości od 1,0 m do 1,6 m jest kompleks ścianowy, wyposażony w kombajn jednoorganowy. Kombajn jednoorganowy łączy w sobie zalety techniki strugowej oraz kombajnowej, eliminując jednocześnie ich podstawowe wady. Przedmiotowe rozwiązanie zostało opracowane w AGH i stanowi obiecujaccą alternatywę dla obecnych kompleksów ścianowych.

Rysunek 11 przedstawia kombajn jednoorganowy (I) posadowiony na przenośniku ścianowym (II). Zgodnie z założeniami kombajn składa się z kadłuba (1), którego głównym zespołem jest jednostka napędowa (2) z zamocowanym na końcu wału frezującym organem przestrzennym (3).

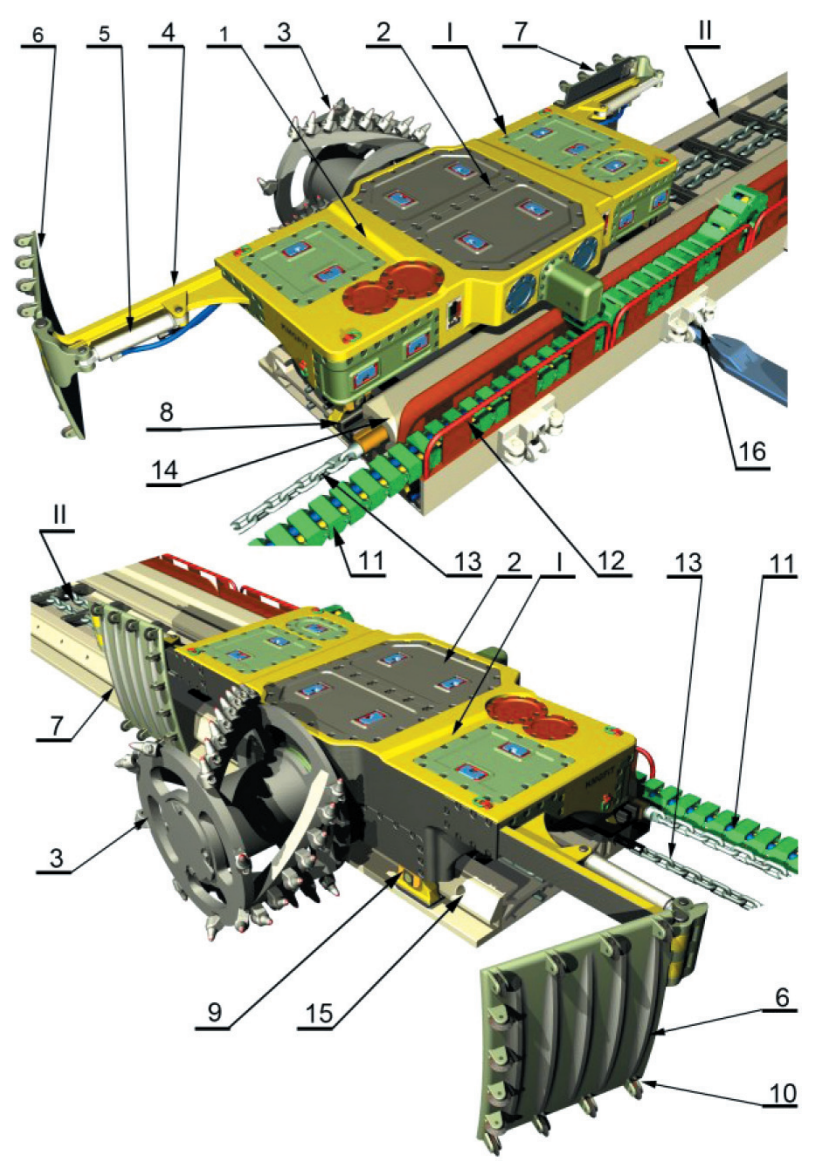

Rys. 11. Rozwiazanie AGH kombajnu jednoorganowego na przenośniku ścianowym

Do kadłuba za pomocą ramion (4) i siłowników (5) mocowane są ładowarki. Ładowarka (6) znajduje się w pozycji aktywnej, natomiast ładowarka (7) w pozycji biernej. Kadłub posiada dwie płozy zawałowe (8) oraz dwie płozy ociosowe (9). Płozy zawałowe (8) połączone są z łańcuchem napędowym (13). Kadłub od strony zawałowej posiada uchwyt układaka (11) z przewodami. Każda ładowarka wyposażona jest 
w rolki (10) zabezpieczające je przed blokowaniem na nierównościach. Przewody znajdują się w układaku (11) i prowadzone są w zastawce (12). Kombajn (I) ciągnięty jest za pomocą łańcucha (13). Płoza ociosowa (9) kombajnu porusza się po prowadzeniu ociosowym (15) przenośnika, natomiast płoza zawałowa (8) porusza się po prowadzeniu zawałowym (14) przenośnika. Kompleks wyposażono w siłowniki korekcji poprzecznej (16).

Rozwiązanie takie umożliwia efektywną eksploatację przedmiotowych pokładów dzięki pracy w systemie ścianowym $\mathrm{z}$ urabianiem dwukierunkowym, zastosowaniu frezowania, rozdzieleniu procesu frezowania od ładowania, zastosowaniu pełnej automatyzacji pracy, cięgnowemu systemowi posuwu, możliwości rozpoczynania nowego skrawu bez konieczności zawrębiania $[14,15]$.

\section{PODSUMOWANIE}

Producenci maszyn górniczych zarówno w Polsce, jak i na świecie oferują wiele typów kombajnów i strugów węglowych, przeznaczonych do pracy w zmechanizowanych kompleksach ścianowych. W szczególności w przypadku kombajnów rozwiązania dostępne w różnych krajach wyraźnie różnią się od konstrukcji klasycznych, a jest to spowodowane lokalnymi uwarunkowaniami tak naturalnymi, jak i gospodarczymi. Opracowany w artykule przegląd i podział kombajnów ścianowych zwraca wyraźnie uwagę na mnogość rozwiązań. Przyczyną takiego stanu rzeczy jest ciągłe poszukiwanie maszyn przeznaczonych do pracy wykreślonych, specyficznych warunkach, jak również rosnące możliwości techniczne, a zwłaszcza rozwój automatyzacji pozwalający na wyeliminowanie człowieka z miejsc szczególnie niebezpiecznych.

Przedstawione, stosowane obecnie kombajny ścianowe nierzadko pozwalają na uzyskanie jedynie kilkuset ton wydobycia dobowego ze ściany, co w polskich warunkach nie jest akceptowalne.

W rozwiązaniach światowych oprócz maszyn tworzących kombajnowe kompleksy ścianowe, stosowane są również maszyny urabiające przeznaczone do innych metod i systemów eksploatacji $[4,5]$.

Zaproponowany przez AGH jako rozwiązanie koncepcyjne i perspektywiczne, kompleks do eksploatacji cienkich pokładów wyposażony jest w kombajn jednoorganowy przeznaczony do pracy w technologii urabiania dwukierunkowego. Charakterystyczną cechą tej technologii, w tym przypadku, jest brak fazy zawrębiania oraz praca na pełny zabiór na całej długości ściany. Zastosowanie organu frezującego pozwala pozytywnie ocenić możliwość wdrożenia takiego kombajnu do pracy w pokładach $\mathrm{z}$ zaburzeniami oraz węglami o najwyższych wskaźnikach skrawalności. Rezygnacja $\mathrm{z}$ realizacji ładowania organami oraz wycofanie obsługi ze ściany eliminuje najważniejsze ograniczenia klasycznej techniki kombajnowej.

\section{Podziękowania}

Prace finansowane z Grantu Dziekańskiego na Wydziale Inżynierii Mechanicznej i Robotyki AGH w ramach umowy numer 15.11.130.838.

\section{Literatura}

[1] Beijing HOT Mining Tech Co., Ltd, www.hotmining.cn [22.05.2018].

[2] Mackina-Westfalia S.A., www.mackina-westfalia.com (20.03.2018).

[3] Corum Group, www.corum.com [22.05.2018].

[4] Kotwica K., Mendyka P., Bołoz Ł. et al.: Wybrane problemy urabiania, transportu i przeróbki skat trudnourabialnych, t. 1, red. K. Krauze, Wydawnictwa AGH, Kraków 2016.

[5] Bołoz L.: Maszyny urabiajace $w$ wybranych metodach eksploatacji cienkich poktadów węgla kamiennego, „Systemy Wspomagania w Inżynierii Produkcji, Górnictwo - Perspektywy i Zagrożenia: Węgiel, Tania Czysta Energia i Miejsca Pracy" 2018, 7, 1: 131-142.

[6] Bołoz L.: Maszyny urabiające w ścianowych systemach eksploatacji cienkich pokładów węgla kamiennego, „Systemy Wspomagania w Inżynierii Produkcji, Górnictwo - Perspektywy i Zagrożenia: Węgiel, Tania Czysta Energia i Miejsca Pracy" 2018, 7, 1: 143-154.

[7] Jaszczuk M.: Ścianowe systemy mechanizacyjne, Wydawnictwo „Śląsk”, Katowice 2007.

[8] Krauze K.: Urabianie skat kombajnami ścianowymi, Wydawnictwo „Śląsk”, Katowice 2000.

[9] Krauze K.: Urabianie skat strugami statycznymi, Wydawnictwo „Śląsk”, Katowice 2012.

[10] Piechota S.: Podstawowe zasady i technologie wybierania kopalin statych, Biblioteka Szkoły Eksploatacji Podziemnej, Kraków 2003.

[11] KOPEX S.A., www.kopex.com.pl [22.05.2018].

[12] Famur S.A., www.famur.com.pl [22.05.2018].

[13] Eickhoff Bergbautechnik GmbH, www.eickhoff-bochum.de [22.05.2018].

[14] Bołoz Ł.: Ocena obciażenia jednoorganowego kombajnu ścianowego na podstawie badań analitycznych, AGH w Krakowie, Kraków 2012 [praca doktorska].

[15] Bołoz L.: Kombajnowy kompleks ścianowy przeznaczony do pracy w niskich ścianach, „Przegląd Górniczy” 2016, 72, 6: 91-97.

dr inż. ŁUKASZ BOEOZ

Katedra Maszyn Górniczych, Przeróbczych $i$ Transportowych

Wydziat Inżynierii Mechanicznej i Robotyki AGH Akademia Górniczo-Hutnicza im. Stanistawa Staszica w Krakowie al. Mickiewicza 30, 30-059 Kraków boloz@agh.edu.pl 